\title{
Vidne til et folkemord
}

\section{Den historiske baggrund for den armenske tragedie og den danske missionær Maria Jacobsens virke}

af Karsten Fledelius, universitetslektor emeritus, cand.mag., Kobenhavns Universitet

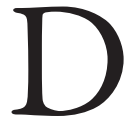
en 12. november 2015 overraktes et politisk og kulturhistorisk klenodie fra begyndelsen af det forrige arhundrede som gave til Det Kongelige Bibliotek. Det drejer sig om den originale, hemmelige dagbog efter den danske sygeplejerske og missioner Maria Jacobsen (18821960), der blev vidne til det armenske folkemord i det østlige Anatolien i Osmannerriget 1915-1919.

Dagbogen omfatter 963 haindskrevne sider i 4 bind omfattende arene 1907-1919; den var ved overrekkelsen ikke overraskende $i$ darlig bevaringstilstand. Bindene smuldrer, men papiret og skriften er generelt velbevaret. Dagbogen er nu under konservering. Den blev overdraget Nationalbiblioteket af historikeren Britta June Claridge Johnsen, der er formand for "Komiteen til Markering af Maria Jacobsens og Karen Jeppes Gerning". I 2015 har komiteen gjort dagbogen tilgangelig $i$ sin helhed $i$ digital form på Nationalbibliotekets hjemmeside.

Maria Jacobsen var fodt i Siim ved Horsens og kom som 24-arig i 1907 som en

\section{Fra Balkan til Anatolien}

Den humanitære og kulturelle katastrofe, Maria Jacobsen blev vidne til 1915-1919 og som er fastholdt i hendes dagbog, havde i virkeligheden sine rødder på Balkan.

Indtil midten af 1700-tallet havde forholdet mellem kristne, jøder og muslimer i det store område, som stadig dækkedes af af de forste kvindelige missionarer til byerne Harput og Mezreh i det nuverende ostlige Tyrkiet, udsendt af Kvindelige Missions Arbejdere (KMA), hvor hun skulle arbejde på et amerikansk drevet missionshospital. I 1916-17 ledte hun militerhospitalet i Mezreh, men maitte give op på grund af vanskelige forhold, men blev frem til 1919 alligevel som den eneste europaiske kvinde alene tilbage $i$ Harput, efter at hendes amerikanske missionarkolleger var rejst hjem.

Under folkedrabet hjalp hun tusindvis afforfulgte armeniere. Hun skrev dagbog om sine oplevelser og beskrev sailedes folkedrabet pà armenierne set indefra. I dag stär dagbogerne som en uvurderlig historisk kilde til begivenhederne på stedet, se bl.a. $<$ folkedrab.dk/sw86798.asp>. Der har $i$ de senere ä også fra dansk side vare forsket $i$ danske kvinders indsats $i$ Tyrkiet under folkedrabet. ${ }^{1}$

Nedenfor giver historikeren Karsten Fledelius baggrunden for den armenske tragedie og den danske missioner Maria Jacobsens virke i Tyrkiet.

Osmannerriget, hovedsagelig været præget af gensidig respekt. Rigets muslimske ledere havde ikke den store interesse i at forvandle skattepligtige kristne og jøder til skattefritagne muslimer. Tværtimod ydede riget asyl ikke blot til fordrevne jøder fra Spanien og Portugal, men også til kristne protestanter og ortodokse, som søgte beskyttelse mod religiøs forfølgelse 


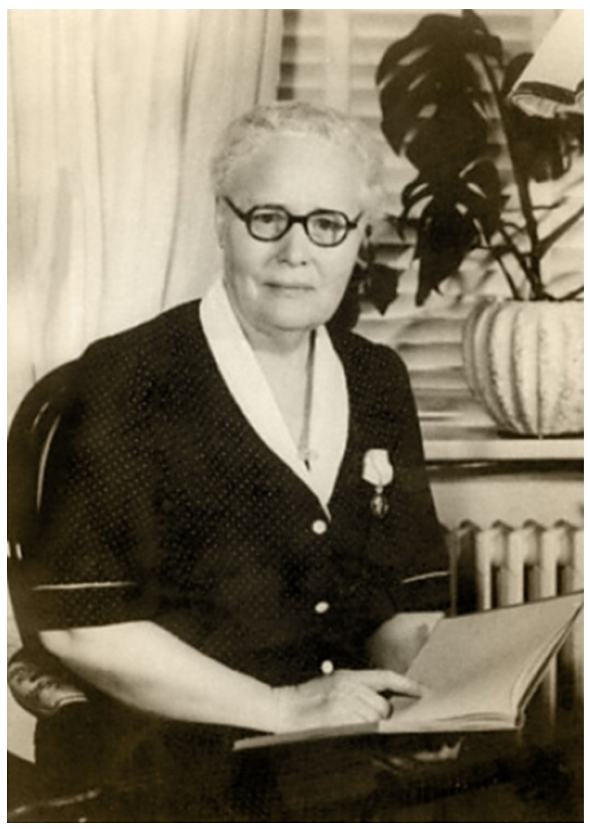

Maria Jacobsen (1882-1960). Foto fra den armenske institution <auroraprize.com>, hvor Jacobsen er biograferet til are for sin indsats for den armenske nation.

i romersk-katolske lande som Østrig, Ungarn og Venedig. Dette nød også armenierne godt af - et kristent folk, hvis kirke, den såkaldte "gregorianske" eller "armensk-apostolske", ikke blev anerkendt som rettroende af andre kristne. De havde deres egne patriarker i Konstantinopel og Jerusalem, foruden deres religiøse overhoveder i Armenien og Kilikien.

I det hele taget var de græsk-ortodokse patriarkater i Konstantinopel, Antiochia, Alexandria og Jerusalem en anerkendt del af Osmannerrigets magtstruktur. Det samme gjaldt deres armensk-apostolske kolleger. Og den rige græske overklasse, "Fanarioterne" fra kvarteret Fener omkring det græske patriarkat i det nordlige Konstantinopel, spillede en vigtig rolle for den osmanniske sultan, som bl.a. brugte medlemmer af denne elite som statholdere i de to kristne, rumænske vasalstater Valakiet og Moldavien.

\section{Den ny-hellenske frihedsbevægelse}

Men andre grækere drømte om en uafhængig græsk nationalstat, ja en genoprettelse af det gamle Byzantinske Rige. Nogle af dem slog sig omkring 1794 ned i den nyanlagte russiske by ved Sortehavet, Odessa, og dannede et broderskab med det formål på Osmannerrigets ruiner at skabe en etnisk hellensk stat.

Disse tanker, der var stærkt påvirket af Den franske Revolution (1789-1804), var bestemt ikke velkomne hos det højere ortodokse præsteskab i Osmannerriget. I 1798 udsendte den græsk-ortodokse patriark af Jerusalem en skarp, teologisk begrundet afvisning af "nyhellenerne", idet han mindede om de osmanniske grækeres pligt til at ære deres retsmæssige hersker, indsat af Gud, sultanen. Men bevægelsen vakte alligevel en vis genklang $i$ de græske eksilmiljøer og ikke mindst hos vesteuropæiske sværmere for den antikke græske civilisation.

1821 forsøgte en græsk "frihedsven", Ypsilantis, fra de rumænsk-talende Donau-fyrstendømmer Moldavien og Valakiet (vasalstater under Osmannerriget) at rykke ned over Balkan mod Konstantinopel i spidsen for en gruppe af ligesindede. Han håbede at få både grækere, rumænere og slavere med sig. Men faktisk var rumænerne ikke særlig interesseret $i$ at udskifte den fjerne sultan med de græske frihedsvenner som deres overherrer. Heller ikke den daværende russiske zar, den konservative Aleksander 1., troede på projektet, som fik en krank skæbne. 


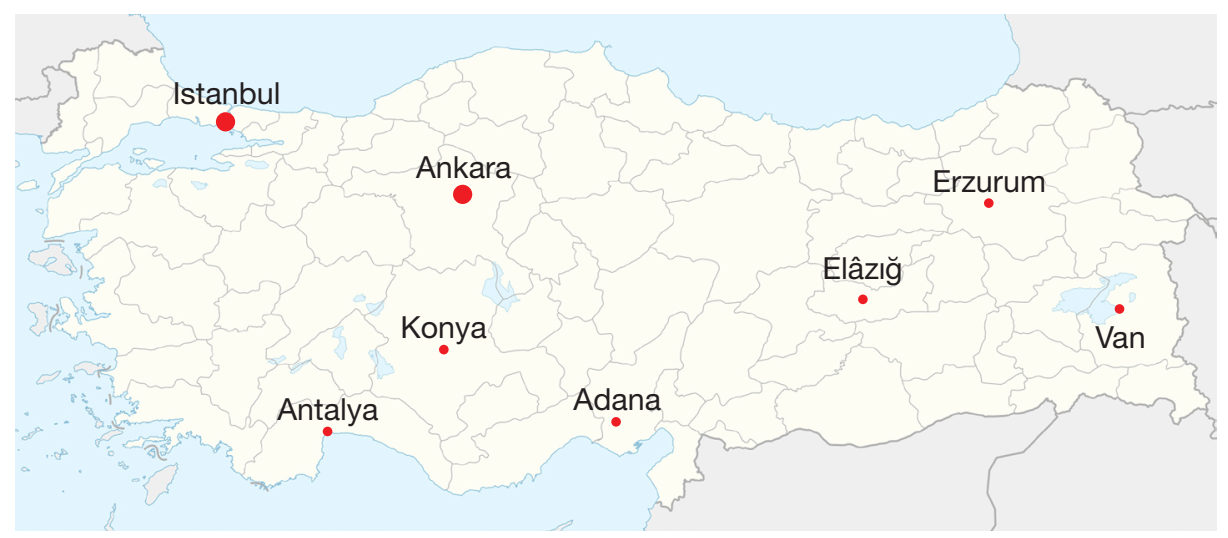

Det moderne Tyrkiet med Elâzı̆ğ (det daverende Harput) midt i Østanatolien (Vestarmenien).

Men på Peloponnes flammede opstanden op, ledet af den stedlige græsk-ortodokse biskop af Patras. Især i halvøens bjergegne strømmede oprørerne til. Sultanen i Konstantinopel, Mahmud 2. (1808-1839), blev grebet af panik, og for at berolige ham besluttede patriarken af Konstantinopel højtideligt at fordømme oprøret og mane rigets grækere til trofasthed og lydighed. Men sultanen så $\mathrm{i}$ fantasien alle sine kristne undersåtter rejse sig mod ham. Han gav ordre til, at patriarken skulle gribes efter påskeliturgien og hænges i patriarkatets port sammen med et par andre biskopper. En lokal bande gik løs på kirken og udførte opgaven, patriarken fik lov til at kvæles langsomt, ophængt i porten, og bagefter blev hans lig i sit festskrud slæbt gennem byen og ned til Bosporus, hvor det med noget tungt om benene blev smidt i vandet.

Imidlertid gik liget ikke til bunds, men flød ovenpå, og blev fisket op af et russisk skib med græsk besætning på vej til - Odessa, centrum for den nyhellenske bevægelse. Herefter bredte opstanden sig hurtigt, især i Sydgrækenland.
Så henvendte Mahmud 2. sig til sin næsten uafhængige vicekonge i Ægypten, albaneren Mehmet Ali, som sendte sin adoptivsøn Ibrahim med en ægyptisk hærstyrke til Peloponnes. Det ægyptiske militær havde lært meget af Napoleons franske invasionsstyrker i 1798, og Ibrahim gik frem på det grusomste. Samtidig angreb den osmanniske flåde øen Khios og massakrerede mange af grækerne der gribende foreviget i den franske kunstner Delacroix' dramatiske billede, som gik det dannede Europa rundt. Det hele endte med, at tidens vigtigste stormagter England, Rusland og Frankrig enedes om en fælles flådeaktion ved Peloponnes, ved Navarino, hvor de i 1827 tilintetgjorde den osmanniske flåde. Russerne rykkede ned gennem Balkan og erobrede i 1829 Adrianopel (Edirne). Så gav sultanen op, og i 1830 blev Grækenland en uafhængig stat.

\section{Truslen om rigets opløsning}

Samtidig havde fyrstendømmet Serbien gjort sig delvist uafhængigt af sultanen. De kristne på Balkan var så småt ved at 
løsgøre sig fra Osmannerriget, lige som de kristne i områderne nord for floderne Donau og Sava tidligere havde gjort. Og følgen af dannelsen af de nye kristne stater blev i høj grad de stedlige muslimers flugt eller fordrivelse. Og mange steder fulgtes det af overgreb mod eller ligefrem tilintetgørelse af muslimske helligdomme. Der var ikke langt fra etnisk til religiøst oprør i en region, hvor man var vant til at definere et "folk" ved dets religion. Allerede ved den østrigske tilbageerobring af Ungarn i 1600-tallet var mange muslimer flygtet herfra til Balkan. De kristnes selvstændighedsbestræbelser sendte flere muslimer på flugt til egne, som stadig var under sultanens kontrol.

Luftige projekter til Osmannerrigets afskaffelse og opdeling dukkede gentagne gange op på dette tidspunkt. Mest "ambitiøs" var den plan, den franske premierminister 1829-1830, hertugen af Polignac, foreslog de øvrige stormagter: Rusland skulle få Donaufyrstendømmerne Moldavien og Valakiet og store dele af Osmannerrigets nordlige asiatiske dele, Ægypten og Syrien kunne blive formelt selvstændige under fransk protektorat, Nordafrika i øvrigt gå til Frankrig, Bosnien og Serbien til Østrig. Resten skulle udgøre en græsk-styret kristen stat med hovedstad i Konstantinopel, et nyt byzantinsk rige med en kristen konge eller kejser.

Af dette ambitiøse program fik Frankrig kun gennemført en lille del: Erobringen af Algier i 1830 - som i øvrigt ironisk nok medførte kong Charles 10.s fald, da kongerigets bedste tropper befandt sig langt fra Paris. Men det nye franske kongedømme under "borgerkongen" Louis Philippe fortsatte en aktiv fransk middelhavspolitik på Osmannerrigets bekostning. Da sønnen af den ægyptiske vice- konge i 1839 foretog et direkte angreb fra Syrien ind i Anatolien og slog Mahmud 2.s tropper afgørende, ønskede Frankrig at støtte dannelsen af et uafhængigt "Storxgypten” bestående af Ægypten, Sudan, Arabien, Syrien, Libanon og Kreta. Men her greb de andre fire stormagter ind og lagde pres på Frankrig, samtidig med at en ny sultan, Mahmud 2.s ganske unge søn Abdül Mecit 1. (1839-1861), proklamerede et reformprogram, som skulle stille alle hans undersåtter tilfreds. I "Gülhanedekretet" (opkaldt efter den park i hovedstaden, hvor reformprogrammet med meget ceremoniel blev forkyndt) garanterede sultanen alle sine undersåtters liv og ejendom, samt indførte retlig ligestilling mellem muslimer, kristne og jøder, et regulært skattesystem og en retfærdig værnepligtsordning. Dette moderniseringsprogram skulle stive Osmannerrigets prestige af over for udlandet og skabe et indtryk af, at det var ved at udvikle sig til en "normal" europæisk stat.

Frankrig opgav dog ikke bestræbelserne efter at skabe et i det mindste delvist uafhængigt Ægypten-SudanSyrien-Kreta, og så det gerne omfatte også Arabien. Men både England og Rusland var nervøse ved at få skabt en ny, stærk militærmagt i Mellemøsten, som kunne true deres interesser i henholdsvis det sydlige og nordligere Asien, og Østrig var bange for en svækkelse af Osmannerriget, som kunne øge Ruslands magt på Balkan. Preussen var ikke direkte involveret, men havde sendt officerer som rådgivere til sultanens hær i Anatolien (bl.a. den fra krigene mod Danmark, Østrig og Frankrig senere så berømte Helmuth von Moltke) og var først og fremmest interesseret $i$ at forhindre Frankrig $i$ at blive for stærkt og dominerende. 

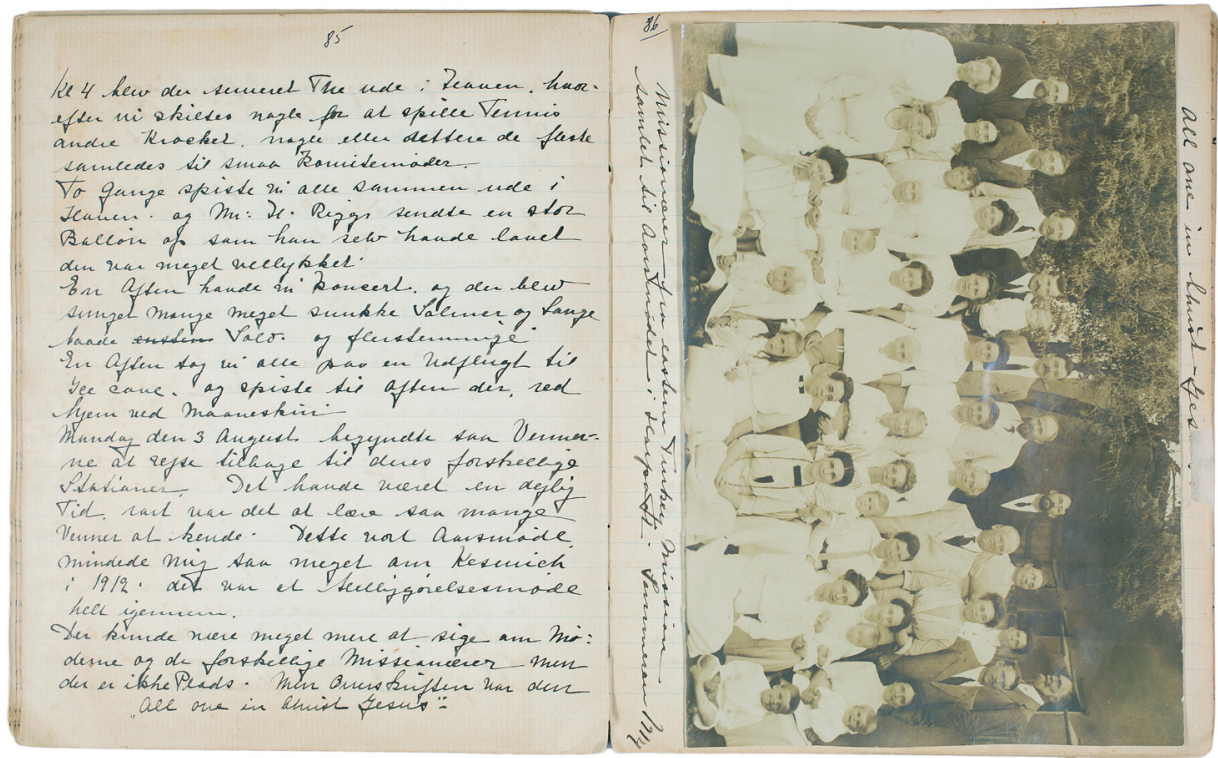

Opslag fra Maria Jacobsens dagbog. Den består affire håndskrevne kladdehefter med en del indsatte fotos fra hverdagen på det amerikanske hospital i Harput (idag: Elâzı̆̆) i det østlige Anatolien, hvor hun tog sig af lokalbefolkningen.

Den deraf udsprungne "Orient-krise" 1839-40 kulminerede med en vellykket engelsk-østrigsk flådeaktion og invasion i Libanon i 1840. Mehmet Ali måtte nøjes med at blive anerkendt som arvelig guvernør i Ægypten og Sudan, men gav afkald på både Kreta, Syrien-Libanon og Arabien. Og franskmændene trak følehornene til sig.

Begivenhederne i $1839-40$ endte således med en styrkelse af sultanen og hans centralregering. Men denne havde påtaget sig en forpligtelse over for udlandet til ikke blot en modernisering, men også en vidtgående sekularisering af Osmannerriget.

\section{Muslimske modreaktioner}

Det sidste udløste betydelig modstand i de muslimske befolkningsgrupper, som hidtil havde befundet sig $i$ en privilegeret position. Således brød der et stort oprør ud blandt den bosnisk-talende muslimske adel i Bosnien-Hercegovina, et oprør som først blev endeligt nedkæmpet i 1850 af sultanens tropper under ledelse af Omar Pasha, en tidligere kroatisk kadet, der var deserteret fra den østrigske hær til den osmanniske og konverteret til islam.

Krim-krigen 1853-56 splittede på ny stormagterne. En strid mellem Rusland og Frankrig om kontrollen over de kristne helligdomme i Palæstina, hvor sultanen støttede det franske synspunkt, førte til et russisk angreb på Osmannerriget, hvis flåde i Sortehavet nærmest blev udslettet. Men Frankrig og England gik til modangreb og belejrede den russiske flådebase Sevastopol på Krim. Freden i Paris gjorde endelig formelt Osmannerriget til en del 
af den "europæiske familie", men dermed kom sultanen og hans regering under endnu stærkere pres fra udlandet for at sikre ordentlige forhold for sine kristne borgere. At skabe en "osmannisk" multietnisk og multireligiøs fællesskabsfølelse baseret på fælles troskab mod dynastiet og valg til et fælles parlament syntes at være midlet til at nå dette mål. Det så ud til at lykkes tre gange, i 1856, 1876 og 1908. Men projektet gik på grund den ene gang efter den anden, pga. både indre og ydre modstand.

Således blev i 1858 en osmannisk straffeekspedition mod Montenegro fanget og tilintetgjort. I 1860 blev mange tusinde kristne massakreret i Damaskus og Libanon. I 1865 indførtes aviscensur, og et oprør mod Osmannerriget på Kreta 1866-67 blev nedkæmpet uden indblanding fra stormagterne. Men da et oprør blandt de kristne i Hercegovina i 1875 året efter bredte sig til bulgarerne - som i modsætning til grækerne, serberne og montenegrinerne endnu ikke havde fået deres egen stat - samtidig med at riget reelt gik bankerot, blev sultan Abdül Aziz (1871-1876) styrtet (og kort efter formentlig myrdet), hvorefter hans bror og efterfølger Abdül Hamid 2. (1876-1909) så sig presset til at indføre en egentlig fri forfatning med parlament og borgerrettigheder. Men samtidig nægtede sultanen at give efter for stormagternes pres om reformer på det slaviske Balkan.

Så greb Rusland igen militært ind, til støtte for bulgarerne. De russiske tropper rykkede ned over Balkan-bjergkæden og nåede helt frem til San Stefano (i dag Yeşilköy) lige vest for Konstantinopel, hvor sultanens udsendinge den 3 . marts 1878 måtte undertegne en ydmygende fred, som skabte et Storbulgarien omfattende ikke blot det nuværende Bulgarien, men også det meste af den osmanniske provins Makedonien. Men en sådan reduktion af sultanens magt så både England, Frankrig og Østrig-Ungarn som en afgørende ændring af den europæiske ligevægt til Ruslands fordel.

Det var i denne situation, at den sidste stormagt i Europa, Preussen - efter 1871 kejserriget Tyskland - tilbød sig som mægler og inviterede til en stor fredskonference i Berlin. Dette initiativ blev taget af kansler Otto von Bismarck, som under henvisning til Tysklands begrænsede interesser i Sydøsteuropa kunne tilbyde sig som neutral mægler. Tysklands interesse $i$ at involvere sig var at placere Berlin centralt i en europæisk fredsproces (efter Wien 1814-15 og Paris i 1856) og give både England, Østrig-Ungarn og Rusland noget at være Tyskland taknemmelig for.

England opnåede en stabilisering af Osmannerriget, som beholdt en bred stribe land tværs over Balkan fra øst til vest, fra det nuværende Europæisk Tyrki til Makedonien, Kosovo og Albanien, og fik samtidig overdraget Cypern som protektorat. Østrig-Ungarn fik overdraget Bosnien-Hercegovina som protektorat og dermed forhindredes dannelsen af et russisk-afhængigt Storbulgarien. Rusland blev godt nok berøvet en del af sejrens frugter, men fik dog oprettet et mindre bulgarsk fyrstendømme og fik nogle af de territoriale tab tilbage, som det havde lidt i forbindelse med Krimkrigen. Vigtigst var nok den russiske erhvervelse af det strategisk vigtige område omkring Kars i det nordøstlige Anatolien. Serberne og montenegrinerne blev snydt for de store territoriale udvidelser, de havde håbet på, men fik dog udvidet deres territorier. 
Ved fredskonferencen i Berlin var der dukket to interessante nye parter op, begge undersåtter til sultanen: nogle repræsentanter for de muslimske albanere i Kosovo, og den armenske patriark i Istanbul. Albanerne plæderede for beskyttelse mod de kristne slavere, patriarken for beskyttelse af de armenske kristne mod deres fjendtlige naboer, først og fremmest de muslimske kurdere. Albanerne fik forhindret, at de kristne slavere satte sig på deres kerneområder i Albanien, Kosovo og Makedonien. Armenierne fik derimod ingenting, ikke andet, end at patriarkens initiativ udløste sultanens udtalte misbilligelse af hele deres folk.

\section{Kaliffens "hellige krig"}

Her spiller det ind, at sultanen over for det russisk-bulgarske angreb havde grebet til det radikale skridt at udnytte sin formelle status som kalif, dvs. religiøst overhoved, til at erklære "hellig krig" mod de vantro russere og deres kristne forbundsfæller. De sidstes befrielseskrig blev dermed omdefineret til en religiøs krig. Og denne linje fortsatte sultan Abdül Hamid 2. efter fredsslutningen. Hvor Abdül Hamid 2.s forgængere havde forsøgt ved reformer at komme kritikken fra Vesteuropa i møde, sad der nu en mand på tronen, som efter at have ladet sig hylde som den gode giver af rigets første frie forfatning, lod som om den aldrig var trådt i kraft for i stedet at spille et helt andet kort - det religiøse. Han spillede både stormagterne og rigets egne indbyggere ud mod hinanden - og først og fremmest muslimerne mod de kristne.

Det havde siden sultan Selim 1.s erobring af Ægypten i 1517 været almindeligt i Mellemøsten at betragte den osmanniske sultan ikke blot som verdslig hersker, kejser, over det tyrkiske rige, men også som gejstlig hersker, kalif, over alle muslimer. Det lykkedes for Abdül Hamid 2. at få Berlin-kongressen til at anerkende denne værdighed, som udstyrede ham med en åndelig autoritet og international prestige, som i det mindste i nogen grad var en kompensation for rigets svindende militære og økonomiske magt. Det lykkedes ham også at få brudt den traditionelle (og af England støttede) teologiske holdning, at kaliffen måtte være etnisk araber.

Tysklands leder, rigskansler Otto von Bismarck var en sekulær realpolitiker, som ikke gav meget for sultanens religiøse lederskab. For ham var støtten til Osmannerriget et middel til at skabe balance $\mathrm{i}$ Europa og Asien. Desuden var der tysk $ø$ konomisk interesse i store transkontinentale jernbaneprojekter, i første række etablering af en jernbaneforbindelse mellem Berlin, Istanbul og Baghdad. I 1883 ankom en tysk militær mission til Konstantinopel og gik i gang med at styrke den tyrkiske officersuddannelse. Men et tættere politisk samarbejde med Osmannerriget lå ikke i kortene for Bismarck.

\section{Wilhelm 2. som sultankaliffens ven}

Dette ændrede sig radikalt, da den nye kejser Wilhelm 2. i 1890 fyrede sin farfars betroede mand og selv tog ledelsen af tysk udenrigspolitik. Den letbevægelige, impulsive, rejse- og eventyrlystne kejser blev fængslet af tanken om et tættere samarbejde med den eksotiske kollega ved Bosporus, hvis arrogante optræden over for sin egen forfatning han ikke så noget odiøst i. Mere ejendommeligt er det, at denne i princippet dybt kristne fyrste tilsyneladende var blind over for, hvad hans kollega foretog sig på hjemmebane 
i relation til sine egne kristne undersåtter især i rigets asiatiske dele.

Sultankaliffen var nemlig i 1890'erne meget optaget af, hvad der foregik ikke blot på Balkan, men også i rigets asiatiske regioner. Han så de kristne befolkningsgrupper, især armeniere, grækere og assyrere, som en sikkerhedstrussel, som han både gennem embedsapparatet og gennem oprettelsen af paramilitære "tæskehold" generede så meget som muligt, i høj grad i "Islams" navn. Dette gik imidlertid ikke ubemærket hen, blandt andet pga. beretninger fra de kristne missionærer, som i stigende antal arbejdede i Østanatolien og Nordsyrien. Da sultanen i perioden 1894-96 optrappede forfølgelserne af de kristne i Asien, hvilket især gik ud over armenierne, skabte det så megen kritik og modvilje i udlandet, at sultanen fik lukket ned for massakrerne og i 1897 erklærede problemerne for løst!

Men der kom et off-spin af massakrerne på armeniere og assyrere: Rygter om lignende massakrer mod grækerne på Kreta udløste græske frivilliges invasion af øen i 1897, senere en direkte intervention af græske soldater, og øen erklæredes for indlemmet i Grækenland. Imens samledes en tyrkisk hær nord for den græsk-tyrkiske grænse i Thessalien under ledelse af en udsendt tysk general, Baron von der Goltz. Tyrkerne invaderede succesfuldt og standsede først lige nord for det historiske pas Thermopylæ - fordi stormagterne denne gang greb ind. Her agerede Englands premierminister Lord Salisbury sammen med Rusland for at forhindre, at så meget som én kristen landsby skulle komme under tyrkisk herredømme igen. Krisen løstes ved, at Kreta forblev under osmannisk overherredømme, men fik en kristen guvernør og en besættelsesstyrke sam- mensat af tropper fra forskellige europæiske magter. Denne ordning, som kunne minde om et moderne FN- eller EUmandat, trådte i kraft i 1898 og varede i det mindste formelt til 1. december 1913 . Osmannerriget havde således formelt bevaret sin hidtidige udstrækning, og for første gang i lang tid havde tyrkiske våben båret en sejr hjem, med et helt centralt og vigtigt bidrag fra tysk side.

Kejser Wilhelm 2. skruede nu yderligere op for charmen over for sin tyrkiske kollega. I 1898 aflagde den rejselystne kejser ligefrem besøg både i Konstantinopel, Damaskus og Jerusalem - tilsyneladende uberørt af den viden, han må have haft om de overlagte massakrer på kristne medborgere, hans vært for nylig havde ladet udvikle sig. Kejserens rejse lignede på overfladen en kristen pilgrimsfærd. Men han fik undervejs sagt adskillige ord om sin store respekt og sympati for verdens muslimer og ikke mindst deres åndelige overhoved, sultankaliffen. Kejser Wilhelm 2. var jaloux på Englands magt, ikke mindst i det rige Indien, han vidste, hvor mange muslimer der faktisk levede der, og så en fremtidig mulighed for, at sultan-kaliffen i Istanbul kunne erklære Hellig Krig ikke blot mod Osmannerrigets, men også Tysklands fjender. Også den tyske tronfølger, kronprins Wilhelm, besøgte sultanen og skriver entusiastisk om hans imødekommenhed, hjertelighed og musikglæde i sine erindringer - ved siden af pave Leo 13. var Abdül Hamid 2. kronprinsens største personlige oplevelse af et udenlandsk statsoverhoved!

Sultanen så på sin side partnerskabet med Tyskland som en mulighed for at hente militær ekspertise til en reform af den osmanniske hær, så den kunne genvinde initiativ og terræn. Og tyskerne 
spillede fortsat gerne med - stadig flere tyske militærrådgivere blev udstationeret i Osmannerriget, og en ny generation af officerer voksede op, undervist af tyskerne. Efterhånden kom store dele af den osmanniske hær og til sidst, i 1914, også flåden under reel overkommando af tyske officerer.

\section{Geopolitik og folkemord}

De nyuddannede tyrkiske officerer var betaget af tyskernes kombination af teknologisk effektivitet, systematisk planlægning og despekt for traditionelle hensyn. Tyskerne bibragte dem større strategisk overblik og meget af den geopolitiske storrums-tænkning, som var udbredt $\mathrm{i}$ vide kredse i tiden, ikke mindst i Tyskland og Rusland. De tyrkiske officersaspiranter havde også noget at lære af den hensynsløshed, som prægede dele af det tyske officerskorps. Det var således den tyske øverstbefalende i Tysk Sydvestafrika, det nuværende Namibia, Lothar von Trotha, som gennemførte 1900-tallets første folkemord. De lokale Herrero- og Nam-folk, som angiveligt havde været ulydige mod den tyske kejser, havde ifølge von Trotha forskertset deres eksistensberettigelse, alle våbenføre mænd og drenge skulle slås ihjel og kvinder og børn tvinges ud i ørkenen til sultedøden. $80 \%$ af Herrero og $50 \%$ af Nam omkom ved denne aktion, som varede fra 1904-1907 og havde mange af de samme træk, som kom til at karakterisere det armenske folkemord 1915-1918.

Det drejede sig i begge de nævnte tilfælde om at få fjernet en befolkning, som lå i vejen for politiske og militære planer. Tankegangen var heller ikke sultanen fremmed, for ham spillede den religiøse dimension dog en større rolle. Abdül Hamid 2. havde ingen tillid til, at der i

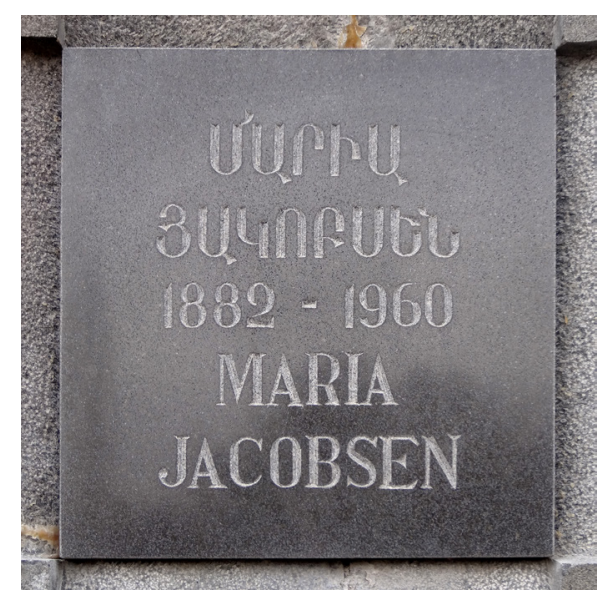

Mindeplade for Maria Jacobsen $i$ Tsitsernakaberd; monumentet for det armenske folkemord i Jerevan. Foto: Wikimedia Commons.

riget kunne skabes en tværnational og tværreligiøs sammenhængskraft baseret på sultanatet og forfatningen. Derfor spillede han "kalif-kortet", som lagde hovedvægten på islam og respekten for Profetens efterfølgers autoritet, både spirituelt og verdsligt. Det betød bl.a., at ikke blot kurderne, men også araberne i højere grad blev inddraget $i$ hans regime, og han var meget stolt over med tysk hjælp (19011908) at få gennemført bygningen af en jernbane fra Damaskus til Medina, for at fremme og lette pilgrimsrejserne til Mekka. I det hele taget var det sultanens vision at knytte riget sammen med jernbaner, over halvdelen af jernbanenettet i det nuværende Tyrkiet er anlagt $i$ hans regeringstid, og også her var tyskerne en stor inspiration og støtte. Men sultanen støttede også bestræbelserne for en nærmere kontakt mellem de tyrkisk-sprogede folk i Europa og Asien, således sendte han en repræsentant til en konference for de tyrkisk-sprogede folk i Pest i Ungarn. 


\section{Ungtyrkerne}

Det nye lag af yngre tyrkiske officerer og deres sympatisører delte gennemgående både sultanens pantyrkiske drømme og hans grundlæggende antipati over for rigets kristne indbyggere - de fleste officerer så det kun som et spørgsmål om tid, hvornår den næste opstand af kristne indbyggere ville bryde ud, under større eller mindre medvirken fra en eller flere kristne stormagter. Personligt var de dog ikke særlig religiøse, snarere sekulært-nationalistiske, de ville af med sultanens selvherskervælde og censur, og de ville selv til magten. I 100-året for Den Franske Revolution, 1889, organiserede de sig i Paris som Yeni Türk "ungtyrkere", men oprettede snart hemmelige kredse i Konstantinopel og fik endda en del af de kristne eliter med sig, herunder grækere og armeniere, som ønskede at få brudt sultanens diktatur.

Dette diktatur var år for år blevet stadig mere dominerende og præget af sultanens dybe mistænksomhed, især efter det attentatforsøg med en tidsindstillet bombe den 21. juli 1905, hvorved en armensk gruppe forsøgte at sprænge sultanen i luften - et forsøg, sultanen kun overlevede ved spontant at ændre tidsplanen. Sultanens modtræk var yderligere at styrke sit hemmelige politi, pressecensuren og andre undertrykkende foranstaltninger.

I 1907 flyttede den ungtyrkiske bevægelses centrum til Thessaloniki og opnåede kontrol med hærens 2. korps i Thrakien og 3. korps i Makedonien sidstnævnte under ledelse af Talaat Pasha, den ene af rigets ledere under Første Verdenskrig. I 1908 gik ungtyrkerne over til direkte at forlange sultanens genindførelse af forfatningen, og de anatolske tropper, som sultanen sendte imod dem, svigtede ham. Derefter fandt han det den 23. juli 1908 klogest at give efter - og i de statskontrollerede medier give det udseendet af, at han gjorde det helt frivilligt! Oprørerne accepterede stiltiende denne "fortælling".

Sultanens udskrivelse af valg til den osmanniske rigsdag fik faktisk en entusiastisk modtagelse af både de tyrkiske, arabiske og kristne eliter. Valgpropaganda-plakaterne fra denne tid, med tekst på både tyrkisk, arabisk og græsk, er rørende i deres loyalitet over for rigsideen og den rituelle respekt for statsoverhovedet. Også mange i udlandet så forfatningens genoplivelse i 1908 som et vigtigt skridt fremad mod en normalisering og europæisering af Osmannerriget. Og det var langt fra alle "ungtyrkere", som var fremmede for visionen om et nyt "osmannisk" fællesskab på tværs af regioner, religioner og sprog, holdt sammen af traditionen, geografien og demokratiet. Også ude i Europa så mange en sådan udvikling med lettelse og forhåbninger.

\section{"Annektionskrisen"}

Én magt fik dog grundigt sat en kæp i hjulet for denne sidste chance for udviklingen af en osmannisk fællesstat mellem muslimer, jøder og kristne. Det var Østrig, som i protest mod, at der ifølge den osmanniske forfatning skulle vælges delegater til den nye rigsdag også i Bosnien-Hercegovina, simpelthen den 5. oktober 1908 erklærede denne provins - som formelt stadig var en del af Osmannerriget - for en del af Det ØstrigUngarske Rige. Det førte til den såkaldte Annektionskrise, som bragte Europa på randen af en stormagtskrig. Bulgariens fyrste Ferdinand 1., som hidtil havde 
anerkendt osmannisk overhøjhed, fulgte i østrigernes fodspor og erklærede sig som uafhængig zar af Bulgarien. Kreta erklærede sig ligeledes for uafhængig af sultanen - men fik dog først sin uafhængighed og forening med Grækenland internationalt anerkendt efter Første Balkankrig i 1913.

Tilsyneladende var dette mindre justeringer af det sikkerhedspolitiske billede på Balkan - der skete ikke egentlige magtskifter nogen af stederne. Og det førte ikke til umiddelbare forringelser for de muslimske indbyggere i Bosnien og Bulgarien. Men begivenhederne 19081909 kom til at få diplomatiske konsekvenser og faktisk lægge brikkerne til rette for udbruddet af Første Verdenskrig. Den østrig-ungarske udenrigsminister havde på forhånd kontaktet sin russiske kollega og diskuteret mulighederne for en kompensation til Rusland for at anerkende annekteringen. Kompensationen skulle være en ophævelse af en international konvention af 1841, som reelt spærrede den russiske flåde inde i Sortehavet, idet den lukkede Bosporus og Dardanellerne, "Stræderne", for udenlandske krigsskibe. Men en ophævelse heraf, som ØstrigUngarn ville støtte, forudsatte britisk og fransk godkendelse. Den blev aldrig indhentet, og ved den ensidige østrigske annektering (som underhånden var støttet af Tyskland) stod Rusland tilbage med et diplomatisk nederlag, foruden at den skabte raseri i Serbien, som på langt sigt havde håbet at indlemme i det mindste en del af Bosnien-Hercegovina, hvis Osmannerriget gik i opløsning.

I 1903 var den østrigsk-venlige serbiske konge Milan Obrenović blevet myrdet, og et russisk-venligt dynasti, Karadjordjević, var kommet til magten i Beograd. Annektionskrisen bragte Ser- bien og Rusland endnu nærmere til hinanden, hvilket blev bemærket både i Wien og Berlin. I januar 1909 brevvekslede den østrig-ungarske generalstabschef Conrad von Hötzendorf hemmeligt med sin tyske kollega Helmuth von Moltke om den opståede situation og nævnte, at man måtte regne med muligheden for, at Rusland i tilfælde af krig mellem Østrig-Ungarn og Serbien ville intervenere til fordel for Serbien. Moltke svarede, at i det øjeblik Rusland skulle mobilisere mod Serbien, ville Tyskland også mobilisere, og det hele sin hær. Den østrig-ungarske udenrigsminister blev klart beroliget ved dette tyske tilsagn, som fik ham til at gå hårdere frem mod Serbien, trods et engelsk forsøg på at give Serbien i det mindste en økonomisk kompensation. Og da det i marts 1909 blev klart, at Rusland ikke ville gå i krig for Serbien, kun tre år efter imperiets ydmygende nederlag til Japan i 1905 , måtte serberne finde sig $i$ at afgive en ydmyg erklæring om godt naboskab.

Osmannerrigets krav til ØstrigUngarn om en kompensation for tabet af Bosnien-Hercegovina lykkedes derimod, med Englands støtte. Østrigerne gik efter hårde forhandlinger med til at betale Osmannerriget omkring 2 mio. engelske pund, hvorefter osmannerne anerkendte annekteringen. Det var et kærkommet tilskud til ungtyrkernes politiske og militære reformbestræbelser, som fortsatte med styrket opbakning fra tysk side.

Godt nok følte en del af de højere osmanniske officerer det ydmygende at skulle underordne sig udenlandske militærpersoner. Men de var betaget af tyskernes systematik og metoder, som begyndte at give dem enkelte sejre, og af tyskernes strategiske overblik, herunder den kombination af teknologisk effekti- 
vitet, systematisk planlægning, bombastisk retorik og moralsk hensynsløshed, som karakteriserede meget af den tyske krigsførelse.

\section{Fra sultanens enevælde til officerernes diktatur}

Hvad det sidste angår, kom de tyrkiske elever dog hurtigt til at overgå deres læremestre. Den politiske borgfred i Osmannerriget efter parlamentsvalget blev kun kortvarig. Et antidemokratisk kup, gennemført af konservative religiøse kræfter, bragte i 1909 kortvarigt sultanens enevælde tilbage på scenen. Men et ekspeditionskorps fra Thessaloniki ledet af en ung oberstløjtnant, Mustafa Kemal (den senere Atatürk), tog jernbanen til hovedstaden og kvalte opstanden. Sultanen blev afsat og forvist til Thessaloniki, hans broder Mehmed 5. Reshad (1909-1918) fik kun rent ceremonielle funktioner, og den ungtyrkiske reformbevægelse satte sig på magten

En del af de kristne eliter trak et lettelsens suk og forventede en tilbagevenden til den inkluderende osmanniske politik. Men ungtyrkerne slog ind på en politik, som ikke blot lå i forlængelse af Abdül Hamid 2.s antikristne spor, men også klart favoriserede det tyrkiske sprog. Dette var en udfordring af rigets ikketyrkiske muslimske folkeslag, araberne, kurderne og albanerne. De sidste havde hidtil loyalt bakket Osmannerriget op, men da regeringen ville forbyde skoleundervisning på albansk i Makedonien og Albanien, voksede utilfredsheden også i denne hovedsageligt ikke-kristne befolkningsgruppe på Balkan.

Ungtyrkerne lededes af et triumvirat, pashaerne (generalerne) Enver, Talaat, og Celal. De var langt fra enige om alt. Enver og Talaat så de kristne som rigets største problem, Celal araberne. Enver var hovedsagelig tyskvenlig, Talaat franskvenlig og Celal russiskvenlig, mens ingen af dem rigtig stolede på Osmannerrigets gamle beskytter, England.

Det havde de heller ikke den store grund til. For i 1911-12 væltede nye katastrofer ind over riget. I 1911 angreb Italien rigets nu vestligste provinser, det nuværende Libyen, og erobrede yderligere De Dodekanesiske Øer i Ægæerhavet. I 1912 rejste albanerne i Skopje sig i protest mod regeringens undertrykkende sprogpolitik, og det fik de kristne nabostater til kollektivt at gå sammen mod tyrkerne. Næsten hele den europæiske del af riget, med byerne Tirana, Priština, Skopje, Thessaloniki og Adrianopel/Edirne, blev erobret af de kristne slavere og grækere. I Konstantinopel tog Enver, Talaat og Celal i fællesskab magten ved et kup i januar 1913, og deres militærdiktatur kom til at vare helt frem til Osmannerrigets kapitulation i oktober 1918. England og Østrig-Ungarn gik ind som mæglere, men resultatet af forhandlingerne i London i juni 1913 blev nedslående: Osmannerriget havde herefter stort set kun hovedstaden tilbage i Europa, selv Albanien blev et selvstændigt fyrstendømme, reelt under østrigsk beskyttelse. Første Balkankrig 1912-13 førte endvidere til en strøm af muslimske flygtninge til Anatolien, og det var en ringe trøst, at de kristne Balkanstater, som havde været "alle mod tyrkerne" i den første krig, i Anden Balkankrig vendte sig mod hinanden, efter princippet "alle mod bulgarerne".

Ungtyrkernes leder og forsvarsminister Enver Pasha, som selv stammede fra Balkan, var som sin kollega Talaat Pasha, som var blevet indenrigsminister, dybt 


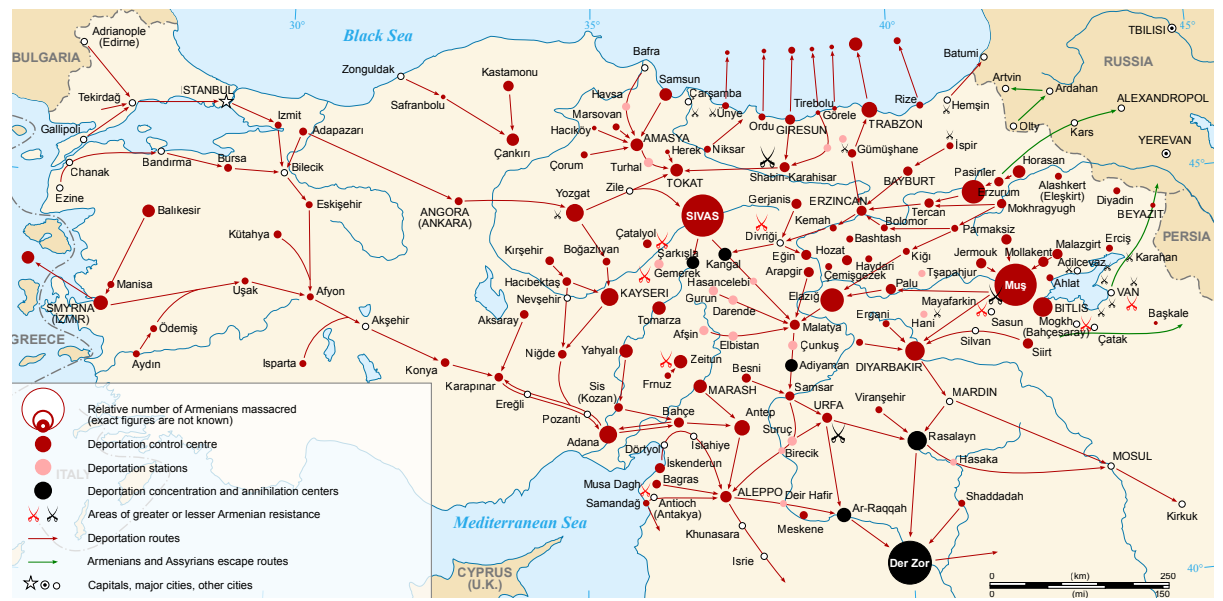

Det armenske folkemord. Oversigtskort fra Wikimedia Commons.

frustreret. De ville besvare hårdt med hårdt. Allerede i 1910 havde Enver udtalt til en tysk gesandt, at armenierne, grækerne og assyrerne havde svigtet imperiet, derfor havde de ikke ret til at overleve, og de skulle i hvert fald fjernes fra de områder, hvor de kunne betragtes som en sikkerhedsrisiko, dels fordi de blev betragtet som en femte kolonne for hovedfjenden Rusland, dels fordi de opfattedes som en grisk middelklasse, som berigede sig på de muslimske bønders bekostning, og endelig fordi de lå i vejen for Envers og Talaats store ide om at skabe et sammenhængende tyrkisk-muslimsk "folkehjem" fra Ægæerhavet til Altaj-bjergene i Sibirien, tyrkernes gamle urhjem. En tanke som i øvrigt heller ikke havde været Abdül Hamid 2. fremmed.

Metoderne hertil kunne de hente inspiration til i den tyske kolonigeneral Lothar von Trothas allerede omtalte udryddelseskampagne mod Herrero- og Nama-folkene i det nuværende Namibia 1904-07 med dens kombination af massakre, udsultning og dødsmarch. Århund- redets andet folkedrab kom Osmannerrigets militærdiktatorer selv til at stå for - også det kom til at strække sig over flere år, helt frem til det tyrkiske militære sammenbrud i slutningen af 1918.

Det var imidlertid klart, at en så radikal operation ville være umulig at gennemføre i fredstid. Erfaringerne fra tidligere årtier viste, at risikoen for stormagtsintervention ville være for stor, og desuden var der langtfra generel tilslutning hertil i de ledende kredse. Endnu i foråret og forsommeren 1914 var det på ingen måde givet, at der ville udbryde en europæisk storkrig, endsige en verdenskrig. Samtidig var der mange, også blandt ungtyrkerne og deres sympatisører, som fandt, at Osmannerriget slet ikke ville kunne klare endnu en krig med nogen udsigt til succes så hurtigt efter de katastrofale balkankrige. Desuden var der stigende irritation blandt de tyrkiske officerer over at være underlagt tysk kommando. Det sidste år før udbruddet af Første Verdenskrig var tyskernes tillid til nytten af investeringer i Osman- 
nerriget endda faldende. Det var mest Wilhelm 2. personligt, som drev på med at opretholde det tyske engagement i Osmannerriget, og krigsminister Enver Pasha, som lagde sig mest op ad tyskerne, mens indenrigsminister Talaat Pasha i foråret 1914 faktisk arbejdede med muligheden for en tilnærmelse til Rusland, og finansministeren støttede en tilnærmelse til rigets traditionelle samarbejdspartnere og kreditorer, England og Frankrig.

Den osmanniske flåde var på dette tidspunkt reelt under engelsk kommando, og riget havde bestilt både et slagskib og flere mindre orlogsskibe i England. To panserskibe var færdigbygget på engelsk værft i sommeren 1914, og deres besætninger var allerede ankommet til England for at overtage dem, da den britiske marineminister Winston S. Churchill den 1. august 1914 simpelthen beslaglagde dem under henvisning til den truende internationale krise. Dette vakte tyrkernes forbitrelse og blev i høj grad udnyttet af den tyske propaganda bestemt for Osmannerriget.

Alligevel trådte rigets regering stadig vande - der forhandledes under hånden til alle sider, men uden at andre end tyskerne tog Osmannerriget alvorligt. To tyske panserskibe, som lå i Ægæerhavet, sejlede op til Konstantinopel og blev med deres tyske besætning overdraget til den osmanniske flåde, som forsynede dem med flotte tyrkiske navne. Og da ansættelsesperioden for den engelske admiral, som havde kommanderet den osmanniske flåde, udløb i september, tog den osmanniske regering imod den tyske admiral Wilhelm Souchon, som herefter fik overkommandoen over flåden. Den afgørende faktor for den tyrkiske tilslutning til centralmagterne blev dog den store tyske sejr over russerne ved Tannenberg i Østpreussen i slutningen af september, som fik Talaat til at opgive enhver tanke om at alliere sig med Rusland og i stedet søge revanche for nederlagene på Balkan i Kaukasus-området.

\section{Krigsudbruddet}

Den udløsende faktor, som bragte Osmannerriget ind $\mathrm{i}$ krigen på tysk side allerede i oktober 1914, blev admiral Souchons uprovokerede angreb på Odessa den 3. oktober fra et af de ex-tyske skibe, efterfulgt af bombardementer af havnebyerne Nikolajevsk og Sevastopol. Den krig, som blev dødsstødet for Osmannerriget, startede således med et angreb på den selvsamme sortehavsby, hvor den første organiserede hellenske frihedsbevægelse mod riget var blevet dannet 121 år tidligere. Men det var mere end noget andet den ubehændige og ydmygende behandling, tyrkerne fik af England lige omkring krigsudbruddet, som endeligt fik drevet Osmannerriget over i Tysklands lejr.

Tyrkerne var dog slet forberedte på krigen. Deres hær var stadig under omstrukturering, rekrutteringssystemet var forældet, og forsyningerne utilstrækkelige. Lokaladministrationen kunne ofte slet ikke følge med. Vilkårlighed og korruption hørte til dagens orden. Det gik ikke kun ud over rigets kristne indbyggere, men også de muslimske. Reelt gik samfundet mange steder helt i opløsning, og nogle lokale embedsmænds forsøg på at opretholde en anstændig forvaltning var de fleste steder forgæves. Det gik galt på fronten mod Rusland, som en overgang trængte helt frem til Trabzon ved Sortehavet. Samtidig koncentrerede 
indenrigsminister Talaat Pasha sig mest om at få udryddet så mange kristne armeniere og assyrere som muligt, med krigen som begrundelse. Ofte sad han ved telegrafnøglen til langt ud på natten for at give ordrer til sine tillidsmænd ude i de østlige provinser. Over for den amerikanske ambassadør Henry J. Morgenthau i Konstantinopel (USA gik først ind i verdenskrigen i 1917) argumenterede både Talaat og hans ministerkollega, stats- og krigsminister Enver Pasha med, at armenierne selv havde gjort sig til fjender af tyrkerne, og at det derfor var legitimt at fjerne dem. Samtidig gik disse ledere let hen over de hårrejsende metoder, de anvendte, samtidig med at de påstod, at de havde alt under kontrol. Men det kaos, deres destruktive energi skabte, forstærkede virkningen af både krigen og forfølgelserne af de kristne, så hele samfundet efterhånden nærmede sig en tilstand af totalt anarki.

\section{Noter}

1 Se Mathias Bjørnlund: Det Armenske Folkedrab. Fra begyndelsen til enden. Kristeligt Dagblads Forlag, 2013, 383 s. Ill; samme: På herrens mark. Nodhjalp, mission og kvindekamp under det armenske folkedrab. Kristeligt Dagblad Forlag, 2015, 265 s. Ill.
$\mathrm{Da}$ Osmannerriget måtte kapitulere i slutningen af oktober 1918, flygtede juntaen og spredtes for alle vinde. I 1919 tog man i det osmanniske parlament, som efter dens flugt forsøgte at redde stumperne af imperiet, fat på et retsopgør, som imidlertid lagde hele ansvaret for folkemordet på juntaen. Enver, Talaat og Celal kom aldrig personligt for retten, men blev dømt til døden in absentia. Alle fik de en voldsom død i udlændighed. Men virkningen af deres handlinger er mærkbare den dag i dag og hænger som en skygge over regionens folkeslag, kristne så vel som muslimske.

Det er imponerende, at der var mennesker af integritet som Maria Jacobsen, som i det forfærdelige kaos havde mod og hjerte til at sætte sig op mod juntaens vanvittige projekt, redde så mange $\mathrm{og}$ lindre lidelserne for endnu flere. Og have styrke og omtanke nok til at fastholde de forfærdelige begivenheder for eftertiden.

Det Kongelige Bibliotek har i forvejen arkivet efter et andet dansk hovedvidne til folkedrabet, missionæren Karen Jeppe (1876-1935), erhvervet i 1986 (Acc.nr. 1986/100). 